\title{
Fsh and Lh direct conserved and specific pathways during flatfish semicystic spermatogenesis
}

\author{
François Chauvigné ${ }^{+}$, Cinta Zapater, Diego Crespo ${ }^{1, \pm}$, Josep V Planas ${ }^{1}$ and Joan Cerdà \\ Institut de Recerca i Tecnologia Agroalimentàries (IRTA)-Institut de Ciències del Mar, Consejo Superior de \\ Investigaciones Científicas (CSIC), Passeig marítim 37-49, 08003 Barcelona, Spain \\ 'Departament de Fisiologia i Immunologia, Facultat de Biologia, Universitat de Barcelona, i Institut de Biomedicina \\ de la Universitat de Barcelona (IBUB), 08028 Barcelona, Spain \\ ${ }^{\dagger} F$ Chauvigné is now at Institute of Biology, Bergen High Technology Centre, University of Bergen, Bergen, Norway \\ ${ }^{\ddagger} D$ Crespo is now at Division of Developmental Biology, Department of Biology, Faculty of Science, \\ Utrecht University, Utrecht, The Netherlands
}

Correspondence

should be addressed

to $J$ Cerdà

Email

joan.cerda@irta.cat

\begin{abstract}
The current view of the control of spermatogenesis by Fsh and Lh in non-mammalian vertebrates is largely based on studies carried out in teleosts with cystic and cyclic spermatogenesis. Much less is known concerning the specific actions of gonadotropins during semicystic germ cell development, a type of spermatogenesis in which germ cells are released into the tubular lumen where they transform into spermatozoa. In this study, using homologous gonadotropins and a candidate gene approach, for which the genes' testicular cell-type-specific expression was established, we investigated the regulatory effects of Fsh and Lh on gene expression during spermatogenesis in Senegalese sole (Solea senegalensis), a flatfish with asynchronous and semicystic germ cell development. During early spermatogenesis, Fsh and Lh upregulated steroidogenesis-related genes and nuclear steroid receptors, expressed in both somatic and germ cells, through steroid-dependent pathways, although Lh preferentially stimulated the expression of downstream genes involved in androgen and progestin syntheses. In addition, Lh specifically promoted the expression of spermatid-specific genes encoding spermatozoan flagellar proteins through direct interaction with the Lh receptor in these cells. Interestingly, at this spermatogenic stage, Fsh primarily regulated genes encoding Sertoli cell growth factors with potentially antagonistic effects on germ cell proliferation and differentiation through steroid mediation. During late spermatogenesis, fewer genes were regulated by Fsh or Lh, which was associated with a translational and posttranslational downregulation of the Fsh receptor in different testicular compartments. These results reveal that conserved and specialized gonadotropic pathways regulate semicystic spermatogenesis in flatfish, which may spatially adjust cell germ development to maintain a continuous reservoir of spermatids in the testis.
\end{abstract}

\author{
Key Words \\ - teleost \\ - follicle-stimulating hormone \\ - luteinizing hormone \\ - transcription \\ - semicystic spermatogenesis
}

Journal of Molecular

Endocrinology

(2014) 53, 175-190 http://jme.endocrinology-journals.org DOI: 10.1530/JME-14-0087
() 2014 Society for Endocrinology Printed in Great Britain
Published by Bioscientifica Ltd 


\section{Introduction}

The pituitary gonadotropins follicle-stimulating hormone (FSH) and luteinizing hormone (LH) are the master regulators of spermatogenesis through the specific binding to their respective cognate receptors in the gonad, the FSH receptor (FSHR) and the LH/chorionic gonadotropin receptor (LHCGR) (Holdcraft \& Braun 2004). In mammals, expression of FSHR and LHCGR is segregated respectively in Sertoli and Leydig cells. In Sertoli cells, FSHR mediates the functions of FSH to enhance spermatogonial proliferation and the entry of spermatogonia into meiosis. In Leydig cells, LH acting via LHCGR induces the production of androgens for the completion of meiosis and spermiogenesis. FSH acts directly or indirectly to modulate gene expression in somatic cells, while affecting few genes in germ cells, whereas less is known concerning the subset of genes controlled by LH during spermatogenesis (Maclean \& Wilkinson 2005, Abel et al. 2009). In non-mammalian vertebrates, such as teleosts, Fsh and $\mathrm{Lh}$ are also preferentially involved in early spermatogenesis and spermiogenesis respectively (Schulz et al. 2010). However, both gonadotropins are potent steroidogenic hormones (Planas \& Swanson 1995) due to direct interaction with their cognate receptors in Leydig cells (Ohta et al. 2007, García-López et al. 2009, 2010, Alam et al. 2010, Chauvigné et al. 2012), while estrogens, androgens, and progestins play important roles during spermatogonial renewal and proliferation, meiosis initiation, and spermiogenesis (Miura et al. 1991a,b, 1999, 2006, Miura \& Miura 2003, Scott et al. 2010).

To gather a more complete picture of the specific actions of gonadotropins on spermatogenesis in nonmammalian vertebrates, recent studies of rainbow trout (Oncorhynchus mykiss), and to a lesser extent of zebrafish (Danio rerio), have begun to identify Fsh- and Lh-dependent genes expressed in the testis and their regulation by steroids (García-López et al. 2010, Rolland et al. 2013, Sambroni et al. 2013a,b). Results from these studies indicate that in contrast to mammals, Fsh and Lh similarly regulate a considerable number of genes in teleosts, where Fsh exerts both steroid-independent and -dependent regulatory functions on many genes relevant for the onset of spermatogenesis and sperm maturation. However, the extrapolation of these findings to Teleostei as a group is limited since these model species have cystic germ cell development, and in some cases, highly cyclic testicular development, whereas some ancient and more evolutionary advanced teleosts, such as
Pleuronectiformes (flatfishes) show semicystic spermatogenesis (Mattei et al. 1993, Weltzien et al. 2004, Schulz et al. 2005, Almeida et al. 2008). In this type of spermatogenesis, germ cells (spermatocytes or spermatids) are released into the seminiferous lumen where they complete meiosis and/or spermiogenesis without direct contact with the Sertoli cells (Mattei et al. 1993, Schulz et al. 2010), but very little is known concerning its regulation by gonadotropins.

The flatfish Senegalese sole (Solea senegalensis) represents a teleost model for studying semicystic spermatogenesis, in which spermatids are released into the lumen of the seminiferous lobules close to the collecting duct where they transform into spermatozoa (García-López et al. 2005, 2006a,b). This species also shows highly asynchronous spermatogenesis since once males reach sexual maturity spermatogenic activity and spermiogenesis are maintained almost all year-round, although spermiation is slightly enhanced during the annual fluctuation of female ovulation (García-López et al. $2006 a, b$ ). Recent studies of sole have revealed a complex cell-type-specific and stage-specific pattern of gene expression during spermatogenesis, and that human chorionic gonadotropin (hCG) can regulate the expression of genes potentially involved in steroidogenesis, progression of spermatogenesis and germ cell maturation (Cerdà et al. 2008, Forné et al. 2009, 2011, Marín-Juez et al. 2011, 2013, Mechaly et al. 2012). However, the specific actions of Fsh and Lh on gene expression during spermatogenesis in Senegalese sole remain unknown. In addition, a non-steroidal Lh/Lhcgr form ba (Lhcgrba) pathway in released spermatids directing spermiogenesis has recently been uncovered in this species (Chauvigné et al. 2014), although the endocrine pathways regulating this process remain to be fully understood.

To gain insights into the gonadotropic regulation of spermatogenesis in Senegalese sole, we performed a comprehensive study to establish the cell-type-specific expression in the testis of candidate genes known to be involved in germ cell proliferation and differentiation in other teleosts. We further investigated their regulation in vitro by Fsh and Lh using homologous recombinant hormones. Our results reveal previously unidentified conserved as well as specialized Fsh and Lh-mediated pathways regulating semicystic spermatogenesis in the testis of sole with respect to other teleosts with cystic spermatogenesis.

Published by Bioscientifica Ltd. 


\section{Materials and methods}

\section{Animals and gonad staging}

Adult Senegalese sole males raised in captivity $(1032 \pm 70 \mathrm{~g}$ in weight; mean \pm s.e.m.) were maintained under natural photoperiod and temperature as described previously (Agulleiro et al. 2006). Fish were anesthetized with 500 ppm of phenoxyethanol, and after a blood sample was taken, fish were weighed and killed by decapitation. The testes were removed and weighed in order to determine the gonadosomatic index (GSI; testis weight/ body weight $\times 100$ ). Different biopsies were deep-frozen in liquid nitrogen and stored at $-80{ }^{\circ} \mathrm{C}$, used for in vitro culture, or processed for histology, immunohistochemistry, and in situ hybridization (ISH) as described previously (Chauvigné et al. 2010). The testes were classified as stages I-II (early and mid spermatogenesis respectively) or stage III (late spermatogenesis) (García-López et al. 2006a) after histological analysis carried out as described previously (Agulleiro et al. 2007). The procedures for the care and use of animals were approved by the Ethics Committee from the Institut de Recerca i Tecnologia Agroalimentàries (IRTA) in accordance with the European Union Council Guidelines (86/609/EU).

\section{Culture of testis explants}

In vitro incubation of testis explants (10-30 mg) and production of Senegalese sole recombinant Fsh and Lh (rFsh and $\mathrm{rLh}$ respectively) were carried out as described previously (Chauvigné et al. 2012). For each experiment in vitro, the testis from one male was dissected transversally into small fragments to assure the presence of the cortical and medullar regions. The explants were incubated in triplicate (one explant per well) with $100 \mathrm{ng} / \mathrm{ml}$ rFsh or rLh at $18{ }^{\circ} \mathrm{C}$ in a temperature-controlled incubator. The replicate explants were treated with $5 \mu \mathrm{M}$ of MDL12330A (MDL; Sigma-Aldrich) or H-89 (Cayman Chemical Company, Ann Arbor, MI, USA), inhibitors of adenylyl cyclase and of cAMP-dependent protein kinase A (PKA), respectively, or trilostane (TRIL; Selleck Chemicals, Houston, TX, USA), an inhibitor of $3 \beta$-hydroxysteroid dehydrogenase $(\mathrm{Hsd} 3 \mathrm{~b}), 1 \mathrm{~h}$ before the hormone treatments. The control explants were incubated with the same concentration of hormone and drug vehicle. After $30 \mathrm{~h}$ of culture, the medium from each replicate was collected, and the testis explants were weighted, deep-frozen in liquid nitrogen, and stored at $-80^{\circ} \mathrm{C}$ until RNA extraction. Three independent experiments on three different males were carried out for each testis stage.

\section{Steroid determination}

The plasma levels of testosterone and $17 \beta$-estradiol $\left(\mathrm{E}_{2}\right)$ were determined in duplicate by RIA (Schering-CIS) as described previously (Palstra et al. 2010), whereas those of 11-ketotestosterone (11-KT) were measured by enzyme immunosorbent assay (EIA; Cayman Chemical Company) as reported (Chauvigné et al. 2012). The levels of testosterone and 11-KT in culture media were determined by EIA and normalized with respect to the weight of the testis explants.

\section{cDNA cloning}

Total RNA extraction from the testis, cDNA synthesis, and RT-PCR were carried out as described previously (Chauvigné et al. 2010). To isolate partial cDNAs encoding Senegalese sole structural maintenance of chromosomes protein 1b (smc1b), cytochrome P450 19a1 (cyp19a1, aromatase), nuclear androgen receptor isoform alpha (ara), nuclear androgen receptor isoform beta (arb), gonadal soma-derived factor variant ( $g s d f)$, and estrogen receptor beta $(e r b)$, oligonucleotide primers were designed from the expressed sequence tags (ESTs) available in GenBank or in the Solea-DB database v2.0 (http:// www.juntadeandalucia.es/agriculturaypesca/ifapa/soleadb_ ifapa/) (Supplementary Table 1, see section on supplementary data given at the end of this article). Alternatively, degenerate primers were used to isolate cDNAs for cytochrome P450scc (cyp11a1), cytochrome P450c17-I (cyp17a1), cytochrome P450c17-II (cyp17a2), 11ß-hydroxysteroid dehydrogenase type 2 ( $h s d 11 b 2)$, and Piwi-like protein 2 (piwi). In some cases, $3^{\prime}$-end UTR regions were amplified using 3'RACE (Life Technologies Corp.). Nucleotide sequences for $s m c 1 b, c y p 19 a 1, a r a, a r b, g s d f, a m h$, erb, cyp11a1, cyp17a1, cyp17a2, hsd11b2, and piwi were deposited in GenBank with the accession numbers listed in Supplementary Table 1.

\section{Immunohistochemistry, immunofluorescence, and ISH}

Immunostaining for sole gonadotropin receptors, Fshr form a (Fshra) and Lhcgr form ba (Lhcgrba) (Chauvigné et al. 2010), were carried out using characterized receptor-specific affinity-purified antibodies as described previously (Chauvigné et al. 2012). For immunofluorescence, sections were counterstained with 4',6-diamidino-2-phenylindole dihydrochloride (DAPI; 1:5000; Sigma-Aldrich) for $3 \mathrm{~min}$ before mounting. ISH was carried out as described previously (Cerdà et al. 2008)

Published by Bioscientifica Ltd. 
using gene-specific riboprobes (Supplementary Table 1). The first post-hybridization washing (50\% formamide in $2 \times \mathrm{SSC}$ at $50^{\circ} \mathrm{C}$ ) was followed by two washes with $0.1-2 \times$ SSC at $42-55^{\circ} \mathrm{C}$ depending on the probes.

\section{Real-time quantitative RT-PCR}

Transcript levels in each replicate testicular explant before (time zero) and after hormone treatment in vitro were determined by real-time quantitative RT-PCR (qRT-PCR) as described previously (Chauvigné et al. 2010, Zapater et al. 2012). The specific primers used are listed in Supplementary Table 1 . The reference gene was elongation factor 1A1 (ef1a1). Real-time qPCR amplifications were carried out in duplicate using $2 \mu \mathrm{l}$ of cDNA diluted 1:101:200 depending on the transcript. The expression levels of fshra and lhcgrba at time zero were normalized only to relative gonad size (receptor $\mathrm{mRNA}$ levels $=\mathrm{qRT}-\mathrm{PCR}$ value/ef1a1 value $\times$ GSI) (Kusakabe et al. 2006) since testis biopsies of similar weight and total RNA content were employed. Changes in gene expression in testicular explants cultured in vitro were determined as fold-changes with respect to untreated explants at time zero using the $2^{-\Delta \Delta C t}$ method. The clustering analysis and heatmap generation for genes differentially regulated by $\mathrm{rFsh}$ and rLh were carried out using the Euclidean method in R software (http://cran.r-project.org).

\section{Immunoblotting}

Protein extraction from testes, treatment with $\mathrm{N}$-glycosidase F (PGNAseF, New England Biolabs, Inc., Ipswich, MA, USA), and immunoblotting using 10\% SDS-PAGE, were performed as previously described (Chauvigné et al. 2012). Triplicate membranes were incubated overnight at $4{ }^{\circ} \mathrm{C}$ with anti-Senegalese sole Fshra or Lhcgrba antisera (1:500), or with anti- $\alpha$-tubulin antibody (Tuba, 1:2000, Sigma-Aldrich T9026). Relative protein abundance was determined from the blots of three different males using the Quantity one software (Bio-Rad) and normalized to relative gonad size (receptor protein levels $=$ receptor band intensity/Tuba band intensity $\times$ GSI).

\section{Statistical analyses}

Data are the mean \pm s.E.M. and were statistically analyzed by the Student's $t$-test, or one- or two-way ANOVA, after log-transformation of the data when needed, followed by the Duncan's multiple range test. A $P$ value $<0.05$ was considered statistically significant.

\section{Results}

\section{Germ cell development and androgen plasma levels during final spermatogenesis}

To identify the Senegalese sole spermatogenic stages investigated in this study, the progression of germ cell development in the cortex and medulla of the testis was examined histologically. At stages I-II, the cortical seminiferous lobules, in which for the majority the central lumen is not yet formed, contained germ cells at all developmental stages (spermatogonia, spermatocytes, and spermatids) and very few spermatozoa (Fig. 1A and E), indicating initiation of meiosis. In the testis medulla, the spermatogenic cysts opened showing mainly free spermatids within the central lumen, which was lined by a thin layer of Sertoli cells, where they start the transformation into spermatozoa (Fig. 1C and E). At stage III, most of the cortical lobules showed an open lumen filled almost exclusively with spermatids and some spermatozoa, although some residual spermatogonia and spermatocytes were also noted in the periphery of the lobules (Fig. 1B and E). However, in the most cortical region of the cortex, beneath the tunica albuginea, spermatogonia and associated Sertoli cells proliferate (Fig. 1B, inset). In the medulla of the testis at stage III, the diameter of the lumen of the lobules was considerably increased and contained large quantities of spermatids and spermatozoa, whereas Sertoli cells were still covering the tubules (Fig. 1D and E). The progression of spermatogenesis from stages I-II to III was associated with a 1.8-fold increase in GSI (Fig. 1F), and with a 2.4- and 1.9-fold increase in plasma levels of testosterone (Fig. 1G) and 11-KT (Fig. 1H), respectively, while circulating levels of $\mathrm{E}_{2}$ were not detected (data not shown).

\section{Fshra is differentially expressed during final spermatogenesis}

The cellular localization of Fshra and Lhcgrba in the testis was investigated by immunohistochemistry, employing specific affinity-purified antibodies (Chauvigné et al. 2012). In the cortex of the testis at stages I-II, Sertoli cells enclosing spermatogonia, spermatocytes, and spermatids strongly expressed the Fshra (Fig. 2A and C), whereas at stage III Fshra expression was no longer detected in the cortical Sertoli cells (Fig. 2B and D). In the medulla, the Fshra was detected in the Sertoli cells forming a thin epithelial-like layer covering the lumen of the seminiferous lobules in the testis at stages I-II and III (Fig. 2E and F). In contrast, Fshra expression in Leydig cells was homogeneous regardless of

Published by Bioscientifica Ltd. 

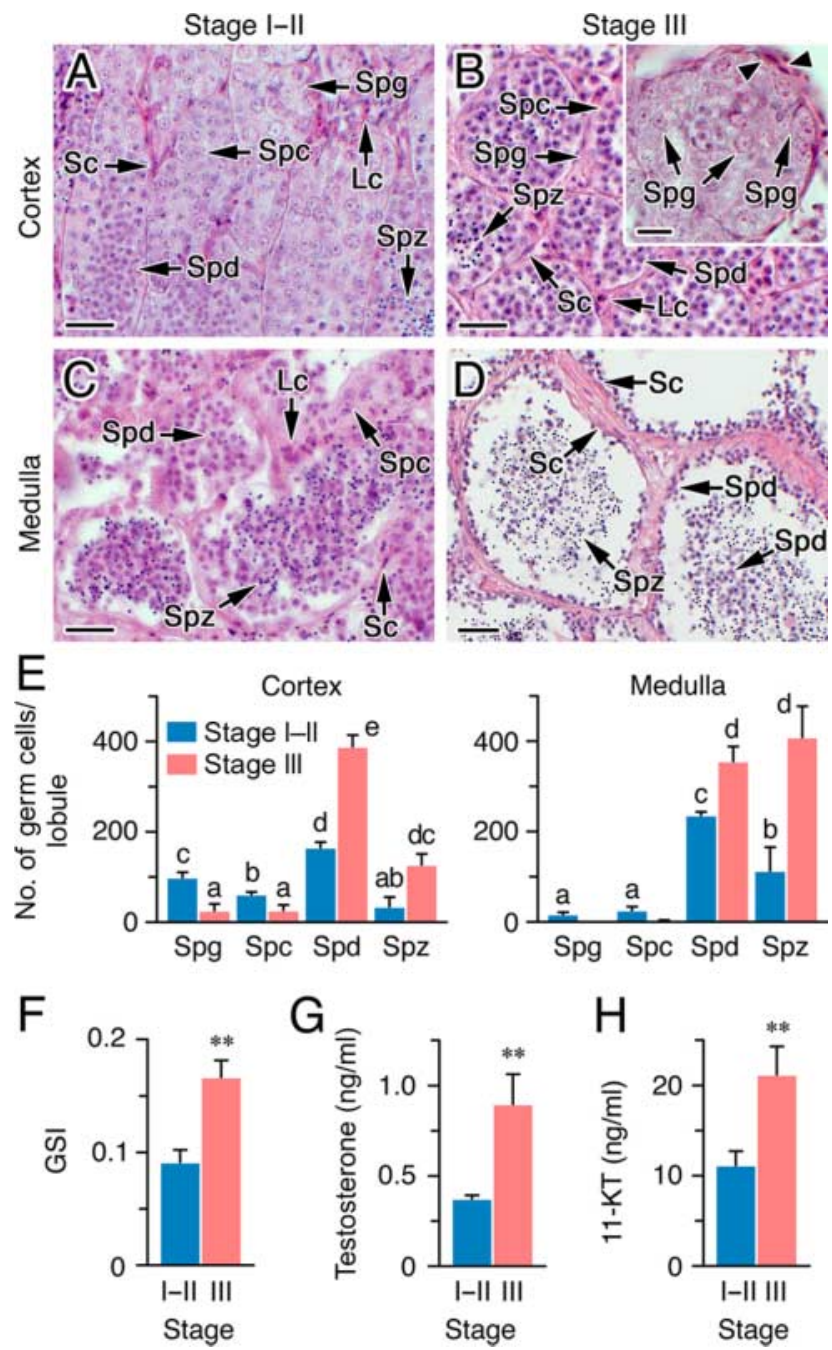

\section{Figure 1}

The final stage of spermatogenesis in Senegalese sole is associated with increased plasma androgen levels. (A, B, C, and D) Representative histological sections of the cortex and medulla of testes at stages I-II and III stained with hematoxylin and eosin. Scale bars, $25 \mu \mathrm{m}$. The inset in B shows the most distal region of the cortex beneath the tunica albuginea of stage III testis. Arrowheads point to proliferating Sertoli cells. Scale bar, $10 \mu \mathrm{m}$. (E) Number of germ cells per seminiferous lobule in the cortex and medulla of testes at stages I-II and III. Bars with different superscript letters are significantly different $(P<0.05)$. In A, B, C, D, and E, LC, Leydig cells; SC, Sertoli cells; Spg, spermatogonia; Spc, spermatocytes; Spd, spermatids; Spz, spermatozoa. (F) GSI of males showing testes at stage I-II or III. (G and H) Plasma levels of testosterone $(\mathrm{G})$ and 11-KT $(\mathrm{H})$ in males showing testes at stage I-II or III. In E, F, G, and H, values (mean \pm s.E.M.; $n=3$ fish) with asterisks $(* *)$ are significantly different $(P<0.01)$. A full colour version of this figure is available at http://dx.doi.org/10.1530/JME-14-0087.

their location or the spermatogenic stage of the testis (Fig. 2A, B, C, D, E, and F). The Leydig cells from the cortical and medullar regions of the testis also expressed the Lhcgrba in a similar fashion at stages I-II and III (Fig. 2G, H, I, J, K, and L). However, while the Lhcgrba was not detected in any of the germ cells of the cortex at either stage I-II or III
(Fig. 2I and J), in the medulla the receptor was present in free spermatids released into the tubular lumen at both stages (Fig. $2 \mathrm{~K}$ and $\mathrm{L}$, insets), thus confirming previous observations (Chauvigné et al. 2012, 2014).

Both the mRNA and protein levels of Fshra and Lhcgrba, as determined by qRT-PCR and western blotting, respectively, were not significantly different between stages I-II and stage III when normalized to the relative gonad size (Supplementary Figure 1, see section on supplementary data given at the end of this article). Immunoblotting of the receptors on the whole-testis extracts revealed, however, a different pattern of glycosylation of Fshra, but not of Lhcgrba, in stages I-II and III (Fig. 2M). At stages I-II, one major Fshra-reactive band of approximately $120 \mathrm{kDa}$ was detected, which disappeared after PNGase F treatment, while a approximately 90-kDa band was induced de novo (Fig. 2M). In contrast, two reactive polypeptide bands of approximately 100 and approximately $110 \mathrm{kDa}$, respectively, were observed in testes at stage III, which were apparently not N-linked glycosylated (Fig. 2M). In both stages, however, the nonmodified Fshra monomer of approximately $78 \mathrm{kDa}$, based on in silico determination of its molecular mass, was barely detectable (Fig. 2M, arrows). In stages I-II and III, testicular Lhcgrba was detected in immunoblotting as major reactive bands with molecular masses of approximately 78, 85, 110, and $150 \mathrm{kDa}$, while PNGase $\mathrm{F}$ treatment only reduced the size of the two higher-molecular-mass bands to approximately $95 \mathrm{kDa}$, probably indicating complex post-translational modifications of Lhcgrba (Fig. $2 \mathrm{~N}$ ).

\section{Lh is more potent than Fsh at stimulating androgen production during final spermatogenesis}

To investigate the steroidogenic action of Fsh and Lh during sole spermatogenesis, explants at stages I-II or III were incubated in vitro in the presence of rFsh and rLh for up to $30 \mathrm{~h}$ and the production of androgens was determined in the culture medium (Fig. 3). At stages I-II, both rFsh and rLh were equally able to stimulate the secretion of testosterone and 11-KT by approximately three- and fivefold above basal levels respectively. At stage III, however, rLh was much more potent than $\mathrm{rFsh}$ at stimulating testosterone (approximately seven- and threefold above basal levels, respectively) and 11-KT (approximately 16-fold and sixfold above basal levels, respectively) production. As expected, in both spermatogenic stages the steroidogenic action of rFsh and rLh involved the cAMP/PKA pathway and 3 $\beta$-Hsd activation since MDL, H-89, and TRIL completely blocked androgen production in vitro (Fig. 3).

Published by Bioscientifica Ltd. 

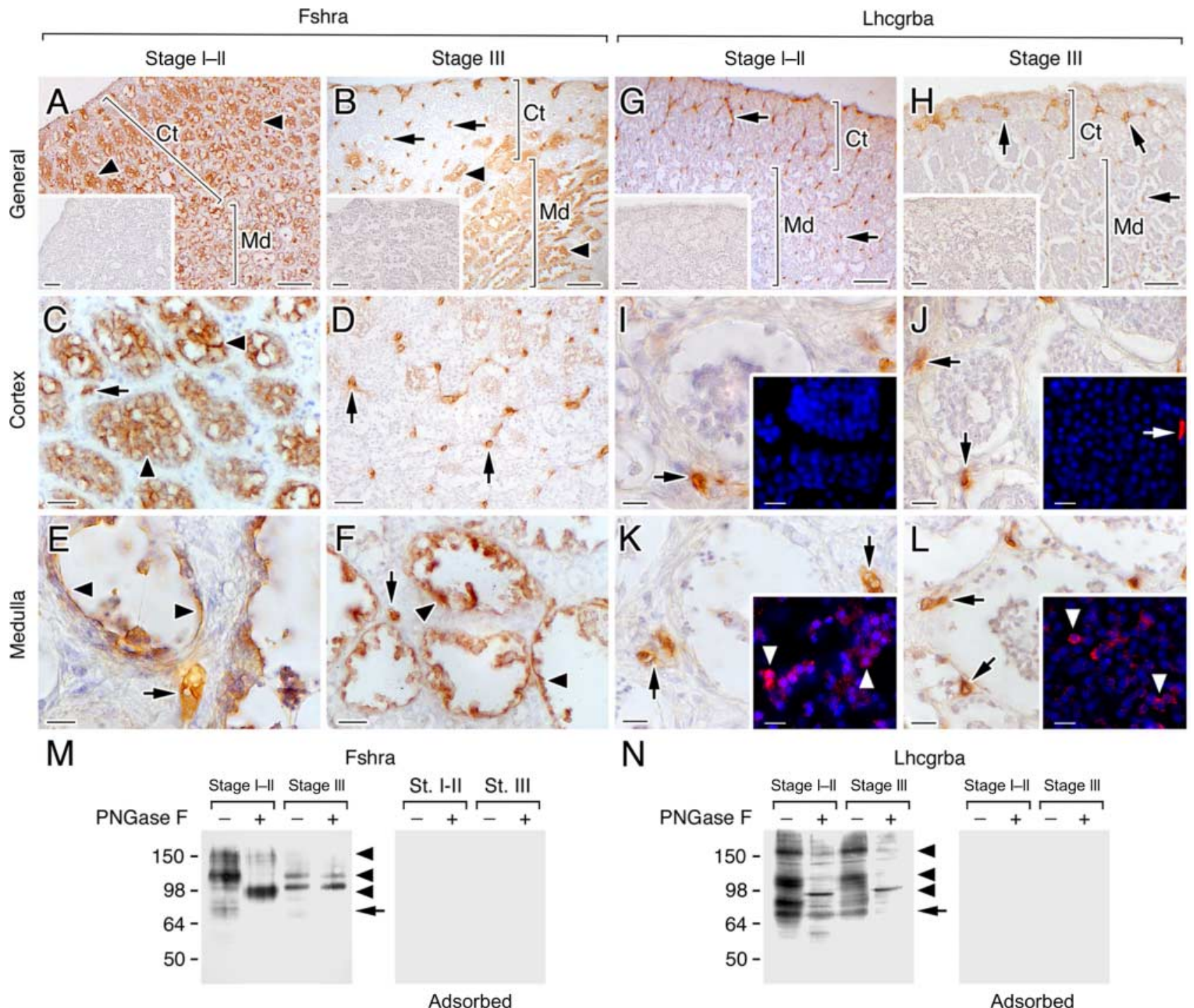

\section{Figure 2}

The expression pattern of Fshra and Lhcgrba in Senegalese sole testes at stages I-II and III of spermatogenesis. (A, B, C, D, E, F, G, H, I, J, K, and L) Immunolocalization of the Fshra (A, B, C, D, E, and F) and Lhcgrba $(G, H, I$, $\mathrm{J}, \mathrm{K}$, and $\mathrm{L}$ ) in the cortex $(\mathrm{Ct})$ and medulla (Md) regions of testes at both stages. The insets in $A, B, G$, and $H$ show control sections incubated with the corresponding antisera preadsorbed with the immunizing peptides. The insets in I, J, K, and L show immunofluorescence staining for Lhcgrba (red) in spermatids (white arrowheads) and Leydig cells (white arrow) superimposed on DAPI (blue) nuclear staining. Arrowheads indicate Sertoli cells, whereas arrows point to Leydig cells. Scale bars, $100 \mu \mathrm{m}$ (A, B, G, and H),

\section{Cell type-specific expression of spermatogenic genes}

The cellular localization in the testis of candidate genes involved in spermatogenesis was determined by ISH using specific riboprobes (Table 1). Most of the transcripts investigated showed a similar cell-type-specific expression in cortex and medulla. The mRNAs encoding steroidogenic enzymes, such as StAR protein (star), hsd3b,
$20 \mu \mathrm{m}$ (C, D, E, F, I, J, K, and L), $10 \mu \mathrm{m}$ (insets in D, I, J, K, and L). (M and N) Representative western blotting of Fshra (M) and Lhcgrba (N) in testes at stages I-II and III. Plus or minus signs indicate preincubation of protein extracts with PNGase F before SDS-PAGE and western blotting. The arrow indicates Fshra or Lhcgrba monomers, whereas the arrowheads indicate the products of PNGase F-sensitive and insensitive posttranslational modifications of the proteins. Duplicated blots (right) were incubated with the primary antibodies preadsorbed with the antigenic peptides to test for specificity. Molecular mass scales $(\mathrm{kDa})$ are shown on the left. A full colour version of this figure is available at http://dx.doi.org/10.1530/JME-14-0087.

17 $\beta$-hydroxysteroid dehydrogenase (hsd17b), cyp17a1, cyp17a2, hsd11b2, 20ß-hydroxysteroid dehydrogenase/ carbonyl reductase-like (cbr1) and cyp11a1, were detected in Leydig cells (Fig. 4A, B, D, E, F, and G), whereas cbr1 and cyp11a1 were also found in spermatids (Fig. $4 \mathrm{H}$ and I). In contrast, cyp19a1 was clearly detected only in spermatids (Fig. 4C). The members of the transforming growth factor

Published by Bioscientifica Ltd. 


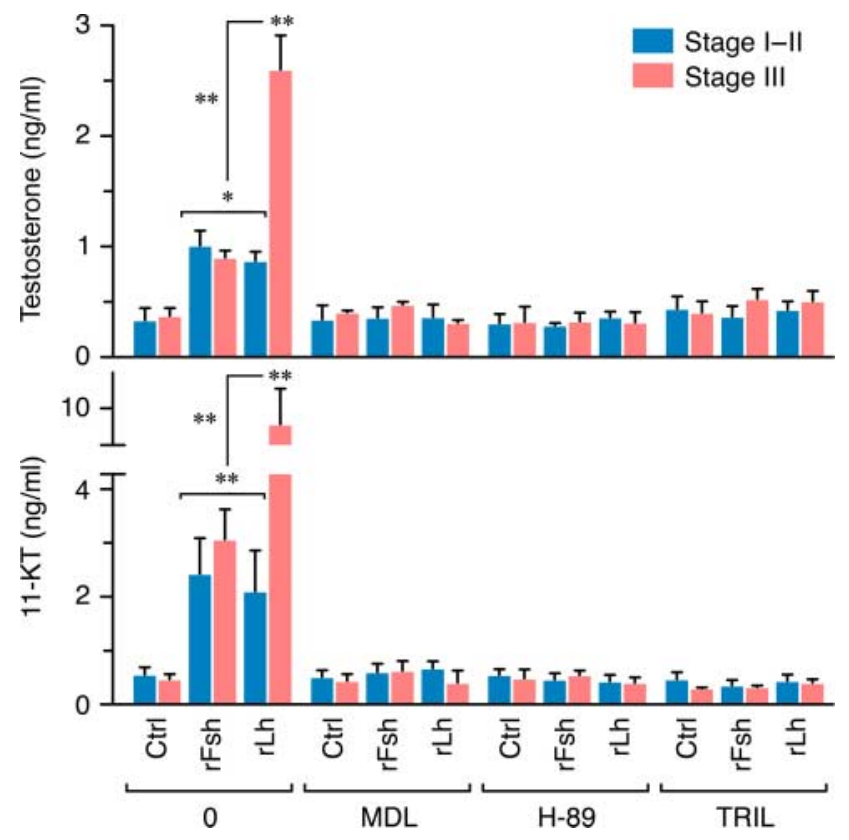

Figure 3

In Senegalese sole both recombinant gonadotropins stimulate testosterone and 11-KT production in vitro. The amounts of testosterone and 11-KT were measured in incubation media after $24 \mathrm{~h}$ of exposure of testis explants at stage I-II or III to $100 \mathrm{ng} / \mathrm{ml}$ of $\mathrm{rFsh}$ and $\mathrm{rLh}$, in the presence or absence of $5 \mu \mathrm{M}$ of inhibitors of the CAMP/PKA pathway (MDL and H-89 respectively) and Hsd-3 $\beta$ (TRIL). Values (mean \pm s.E.M.) are from three independent experiments on three different males, each with three replicates per condition. Asterisks denote significant differences $(P<0.01)$ with respect to the groups treated with the inhibitors, or as indicated. A full colour version of this figure is available at http://dx.doi.org/10.1530/ JME-14-0087.

beta (Tgfb) superfamily, such as $g s d f$ and anti-Müellerian hormone $(a m h)$, were expressed in Sertoli cells only (Fig. 5A and B), and in the case of $g s d f$ exclusively in the cortical region (Fig. 5A, inset). The Sertoli cells also expressed insulin-like growth factor 1a (igf1a) (Fig. 5G). Interestingly, late germ cells (spermatocytes and spermatids) expressed insulin-like growth factor 1 receptor-like (igf1rl) (Fig. 5H). The nuclear androgen receptors ara and arb showed specific localization in germ cells (spermatogonia, spermatocytes, and spermatids) (Fig. 5D) or in Sertoli cells (Fig 5E) respectively. The erb and nuclear progestin receptor ( $p g r$ ) transcripts were also observed in all germ cells (Fig. 5C and F), as well as in Leydig and Sertoli cells respectively. Finally, the meiosis-related genes piwil2 and $s m c 1 b$ were expressed in spermatogonia, spermatocytes, and spermatids (Fig. 5I and J), whereas transcripts encoding spermatozoa differentiation genes such as septin 7a (sept7a) were only found in spermatids (Fig. 5K).

\section{Fsh and Lh regulation of spermatogenic genes in vitro}

The gonadotropic regulation of the expression of the 20 selected transcripts, plus fshra and lhcgrba, as well as radial spoke head 1 homolog (rsph1) and StAR protein-like (starl) previously characterized (Chauvigné et al. 2010, 2014, Marín-Juez et al. 2011), was investigated in testes explants at stages I-II and III using rFsh and rLh. The results of the qRT-PCR experiments showed that the levels of all transcripts changed in response to $\mathrm{rFsh}$ and/or rLh except for fshra and piwil2 (Supplementary Figure 2, see section on supplementary data given at the end of this article). Clustering analysis of significantly differentially expressed transcripts indicated that most of the genes were under gonadotropic regulation at stages I-II while very few were regulated at stage III (Fig. 6). In stages I-II, three main clusters of genes were defined based on the relative potency of rFsh and rLh for regulating gene expression (Fig. 6A). The first cluster contained genes preferentially upregulated by rFsh and included the Sertoli cell growth factors $g s d f$ and $a m h$, together with some steroidogenesisrelated genes such as $h s d 3 b, c y p 17 a 1$, and cyp17a2 in Leydig cells; gsdf and amh being the most stimulated (approximately fivefold) genes. The second group was formed by genes primarily activated by rLh and included other steroidogenesis-related genes such as $c b r 1$, hsd11b2, and cyp11a1; the nuclear receptors pgr and arb; the lhcgrba; and the spermatozoa differentiation genes sept7a and rshp1. The transcript most highly stimulated by rLh was hsd11b2 (approximately fourfold). Finally, the third cluster included those genes equally upregulated by both gonadotropins such as the rest of the steroidogenic genes, star, starl, hsd17b, and cyp19a1 and erb, ara, and scm 1 b. At stage III, rFsh stimulated predominantly the expression of $a r b$, star, and $p g r$, rLh specifically increased igf $1 r$ and $h s d 17 b$, and both gonadotropins slightly promoted the expression of igf1, cyp17a1, and $c b r 1$ (Fig. 6B).

\section{Steroid-dependent and -independent actions of gonadotropins on testicular gene expression}

To investigate whether the effect of gonadotropins on gene expression was dependent on steroid production, the expression levels of gonadotropin-regulated genes in explants at stages I-II treated with $\mathrm{rFsh}$ and $\mathrm{rLh}$ in the presence of MDL, H-89, or TRIL were determined by qRTPCR (Fig. 7). The gonadotropic regulation of most of the genes analyzed, including Sertoli cell factors (amh and gsdf) (Fig. 7A and M), steroidogenic genes ( $h s d 3 b, c y p 17 a 1$, cyp17a2, cyp11a1, hsd17b, cbr1, hsd11b2, and starl)

Published by Bioscientifica Ltd. 
Table 1 Cell type-specific gene expression in the Senegalese sole testis determined by ISH

\begin{tabular}{l} 
Gene \\
\hline fshra \\
Ihcgrba \\
gsdf \\
amh \\
igf1a \\
igf1rl \\
ara \\
arb \\
pgr \\
erb \\
piwil2 \\
smc1b \\
rsph1 \\
sept7a \\
star \\
starl \\
cyp11a1 \\
hsd3b \\
cyp17a1 \\
cyp17a2 \\
hsd17b \\
cyp19a1 \\
cbr1 \\
hsd11b2 \\
rat
\end{tabular}

\section{Protein product}

Follicle-stimulating hormone receptor form a

Luteinizing hormone receptor form ba

Gonadal soma-derived factor

Anti-Müellerian hormone

Insulin-like growth factor 1 form a

Insulin-like growth factor 1 receptor-like

Nuclear androgen receptor isoform alpha

Nuclear androgen receptor isoform beta

Nuclear progestin receptor

Estrogen receptor beta

Piwi-like protein 2

Structural maintenance of chromosomes protein form b

Radial spoke head 1 homolog

Septin 7a

StAR protein

StAR protein-like

Cytochrome P450scc

3 $\beta$-hydroxysteroid dehydrogenase

Cytochrome P450c17-I

Cytochrome P450c17-I

$17 \beta$-hydroxysteroid dehydrogenase

Cytochrome P450 19a1 (aromatase)

20ß-hydroxysteroid dehydrogenase/carbonyl reductase-like

$11 \beta$-hydroxysteroid dehydrogenase type 2

\section{Cell type}

Sc, $\mathrm{LC}^{\mathrm{a}}$

Lc, Spd ${ }^{a, b}$

Sc (only cortical)

Sc

Sc

Spc, Spd

Spg, Spc, Spd

$\mathrm{SC}$

Sc, Spg, Spc, Spd

LC, Spg, Spc, Spd

Spg, Spc, Spd

Spg, Spc, Spd

Spd

Spd

LC

$\mathrm{LC}^{\mathrm{a}}$

LC, Spd

LC

LC

LC

Lc

Spd

LC, Spd

LC

Lc, Leydig cell; Sc, Sertoli cell; Spg, spermatogonia; Spc, spermatocyte; Spd, spermatid.

${ }^{a}$ Reported by Chauvigné et al. $(2010,2012)$.

${ }^{\mathrm{b}}$ Reported by Chauvigné et al. (2014).

(Fig. 7B, C, D, H, I, J, K, O, and P), nuclear receptors arb and pgr (Fig. 7L and F), and smc1b (Fig. 7N), was completely abolished by MDL, H-89, and TRIL, indicating that the effect of both rFsh and rLh on these genes was dependent on steroids produced via the cAMP/PKA pathway. However, the stimulation of star by rFsh (Fig. 7O), and of lhcgrba and sept7a by rLh (Fig. 7E and G), was reduced or suppressed in the presence of MDL and H-89 but not in the presence of TRIL, indicating that these effects were steroid-independent.

\section{Discussion}

\section{Differential expression and regulation of gonadotropin receptors}

The present work shows that between spermatogenic stages I-II and III, the overall Fshra and Lhcgrba protein levels in the sole testis remained unchanged, which is consistent with the absence of in vitro testicular fshrainduced expression by Fsh and Lh during these stages. In contrast, Lh slightly increased lhcgrba expression at stages I-II through a steroid-independent mechanism. Since sole Lhcgrba is expressed in Leydig cells and medullar mature spermatids free in the tubular lumen, it is possible that Lh stimulates the expression of its own receptor in these cells. Interestingly, immunohistochemistry revealed that Fshra was no longer expressed specifically in the cortical Sertoli cells at stage III, which was probably masked in analyses of the total protein levels in the testis because of the enlargement of the medullar Sertoli cells, which constitutively express the receptor. This finding indicates that during late spermatogenesis in sole, the effects of Fsh on gene expression in cortical Sertoli cells, including genes that may control Sertoli cell and spermatogonial proliferation, are probably indirect and mediated by steroids produced by Leydig cells. In addition, we noted that the Fshra was no longer N-linked glycosylated at stage III, which can potentially affect negatively the intracellular processing of the receptor (Menon et al. 2005). Altogether, our observations indicate that in sole during late spermatogenesis, Fshra is downregulated through translational and post-translational mechanisms.

\section{Convergent effects of Fsh and Lh on gene expression}

In the present study, we found that most genes involved in steroid production were significantly upregulated by both Fsh and Lh at stages I-II, which correlated with an increased production of androgens by the testicular

Published by Bioscientifica Ltd. 
Antisense
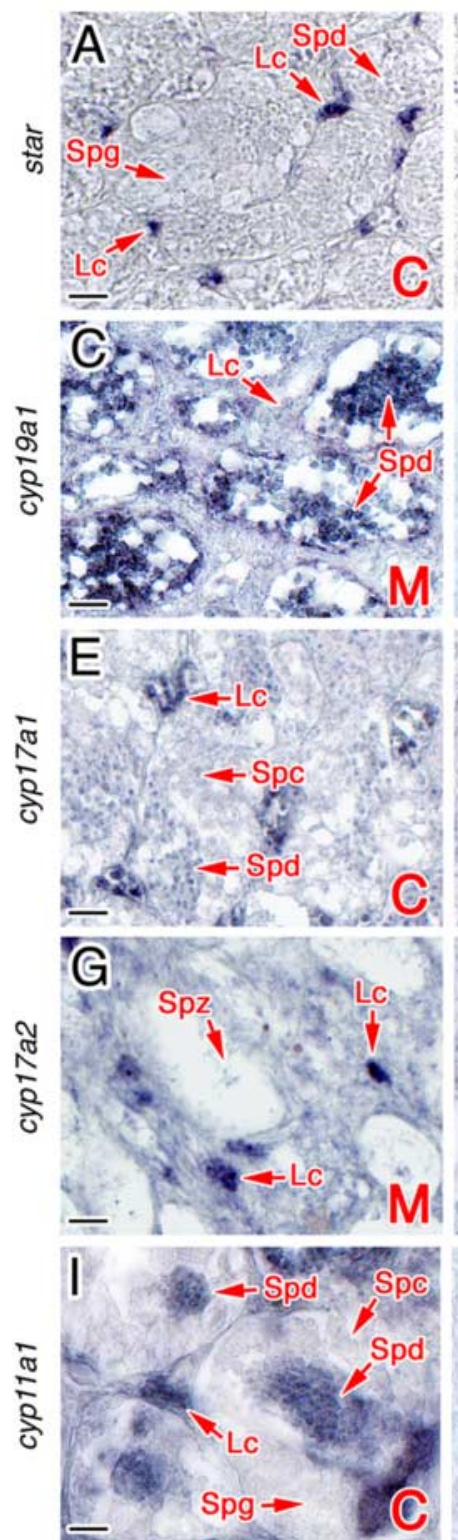

Sense
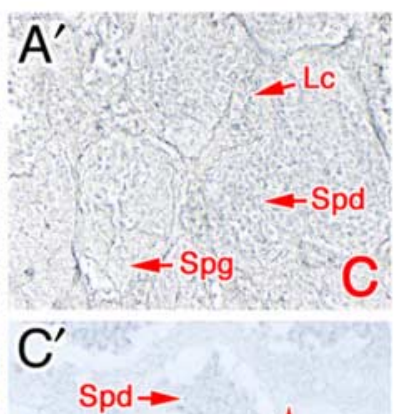

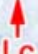

M
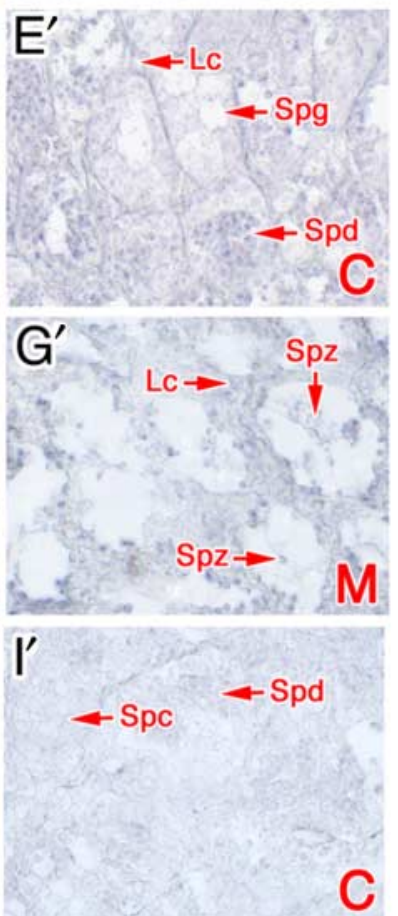

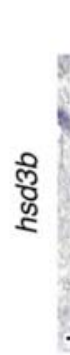

Antisense
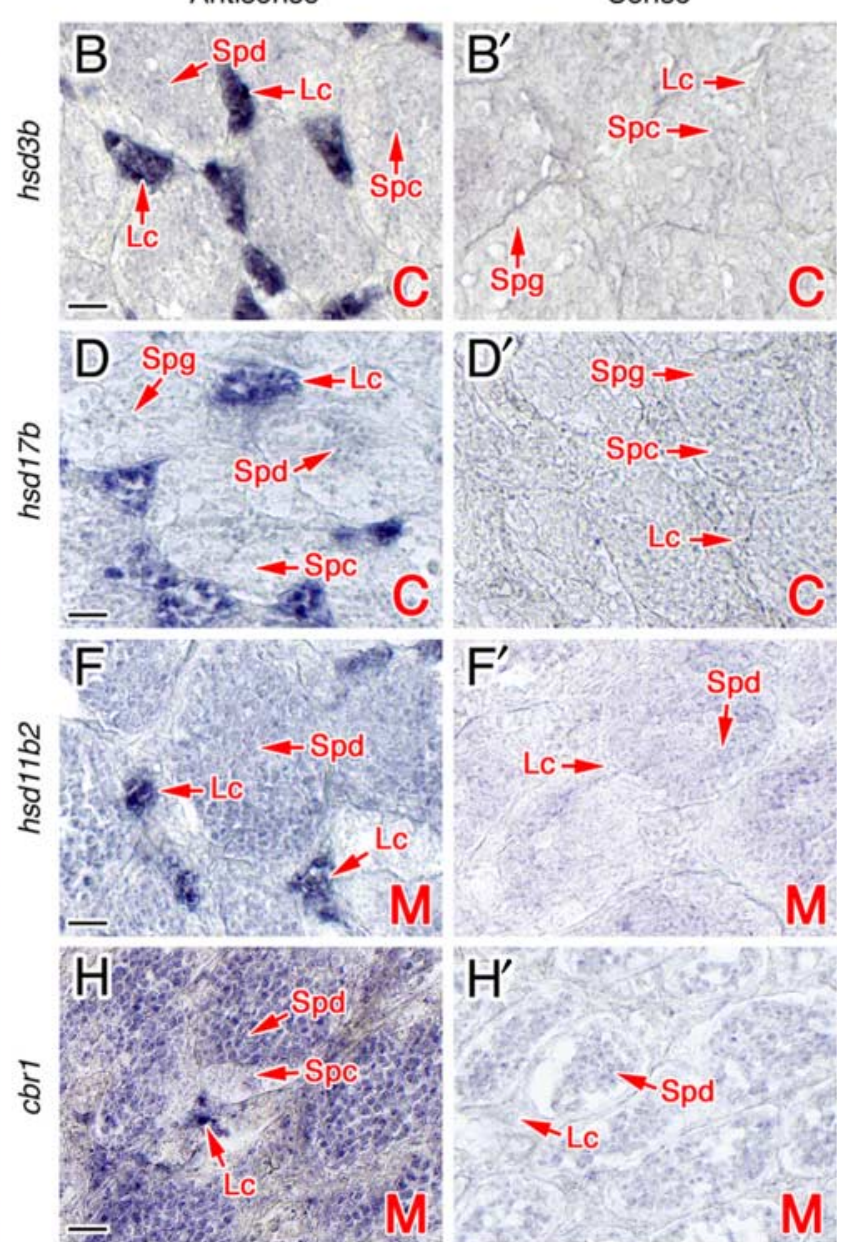

\section{Figure 4}

Localization of steroidogenesis-related transcripts in the Senegalese sole testis by ISH. Paraffin sections of testis were hybridized with antisense DIG-labeled riboprobes specific for star (A), hsd3b (B), cyp19a1 (C), hsd17b (D), cyp17a1 (E), hsd11b2 (F), cyp17a2 (G), cbr1 (H), and cyp11a1 (I).

The hybridization signal is colored dark-blue to purple. $\left(A^{\prime}, B^{\prime}, C^{\prime}, D^{\prime}, E^{\prime}, F^{\prime}\right.$, $\mathrm{G}^{\prime}, \mathrm{H}^{\prime}$, and $\mathrm{I}^{\prime}$ ) Control sections stained with sense probes. The region of

explants at these stages in vitro. This is in agreement with previous in vivo data for Senegalese sole obtained using hCG (Marin-Juez et al. 2011), and is probably mediated by the presence of the Fshra and Lhcgrba in Leydig cells (Chauvigné et al. 2012). Our current data indicate, however, that at stages I-II, Fsh preferentially stimulates the expression of enzymes upstream of the steroidogenic the testis shown in each photomicrograph, cortex (C) or medulla (M), is indicated with red letters. Lc, Leydig cell; Sc, Sertoli cell; Spg, spermatogonia; Spc, spermatocyte; Spd, spermatid; Spz, spermatozoa. Scale bars, $20 \mu \mathrm{m}$. A full colour version of this figure is available at http://dx.doi.org/ 10.1530/JME-14-0087.

pathway, such as $h s d 3 b, c y p 17 a 1$, and cyp17a2, whereas Lh was more potent at promoting the expression of $h s d 11 \mathrm{~b} 2$, involved in the conversion of testosterone into 11-KT, and of $c b r 1$, responsible for the conversion of $17 \alpha$-hydroxyprogesterone into $17 \alpha, 20 \beta$-dihydroxy-4-pregnen-3-one $(17,20 \beta-P)$, a progestin implicated in entry into meiosis and spermiation in teleosts (Miura et al. 2006, Scott et al. 2010). 


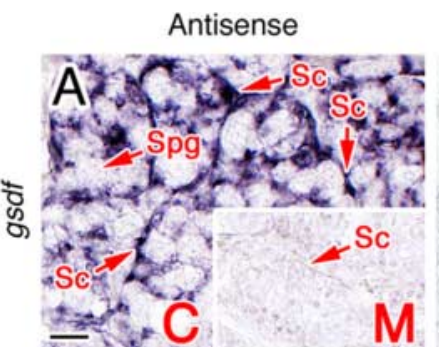

Sense
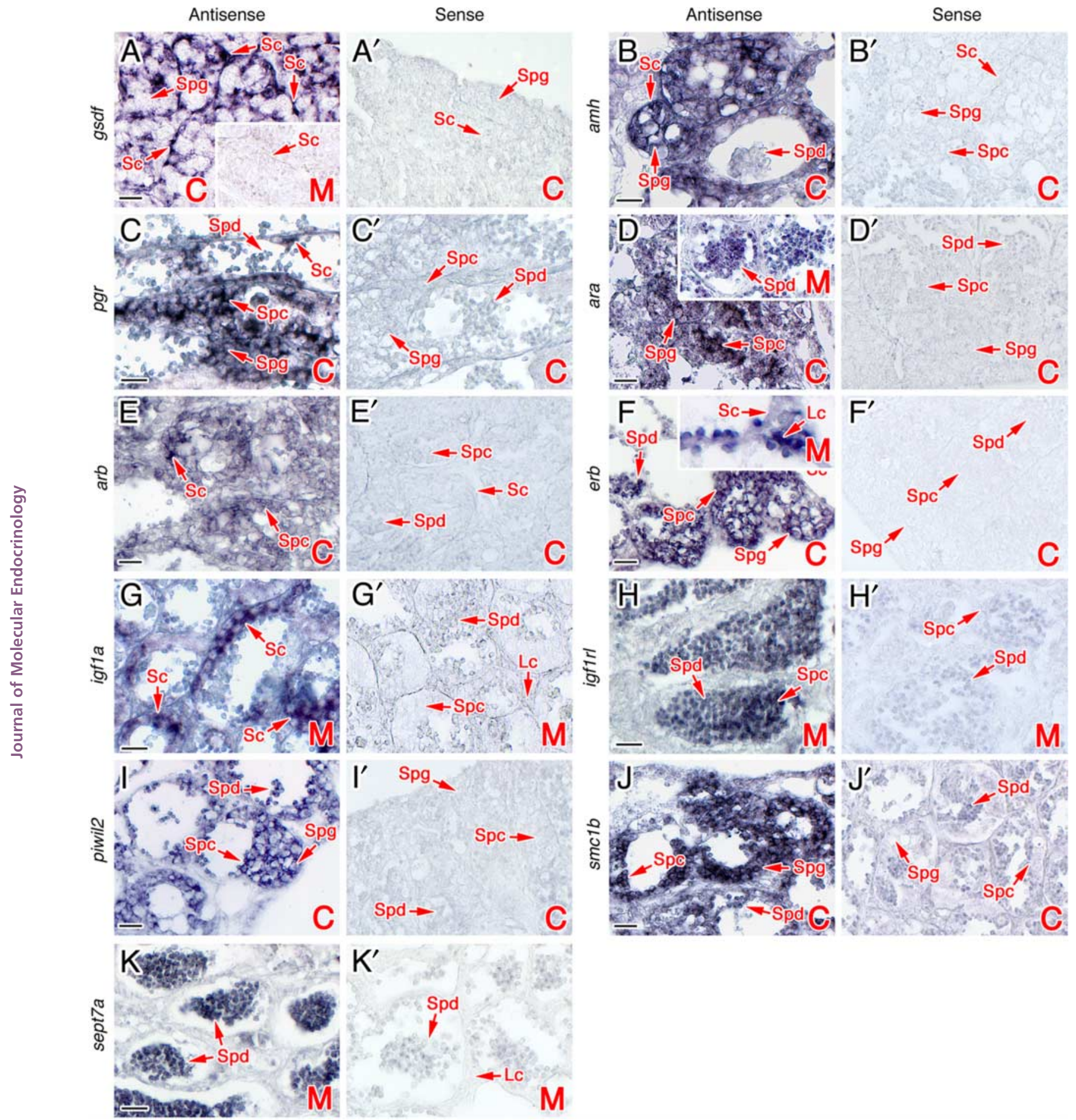

Figure 5

Localization of transcripts encoding growth factors, nuclear receptors, and meiosis-related markers in the Senegalese sole testis by ISH. Paraffin sections of testis were hybridized with antisense DIG-labeled riboprobes specific for gsdf (A), amh (B), pgr (C), ara (D), arb (E), erb (F), igf1a (G), igfr1 $(\mathrm{H})$, piwil2 $(\mathrm{I})$, smc1b $(\mathrm{J})$, and sept7a $(\mathrm{K})$. The hybridization signal is colored dark-blue to purple. $\left(A^{\prime}, B^{\prime}, C^{\prime}, D^{\prime}, E^{\prime}, F^{\prime}, G^{\prime}, H^{\prime}, I^{\prime}, J^{\prime}\right.$, and $\left.K^{\prime}\right)$ Control sections

stained with sense probes. The region of the testis shown in each photomicrograph, cortex (C) or medulla (M), is indicated by red letters. Lc, Leydig cell; Sc, Sertoli cell; Spg, spermatogonia; Spc, spermatocyte; Spd, spermatid. Scale bars, $20 \mu \mathrm{m}$. A full colour version of this figure is available at http://dx.doi.org/10.1530/JME-14-0087. 
A

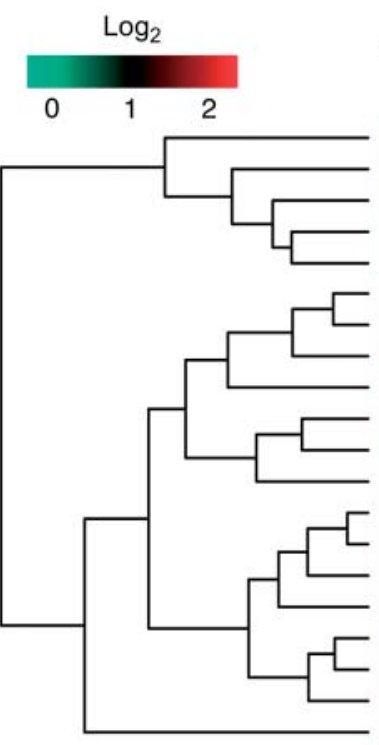

B

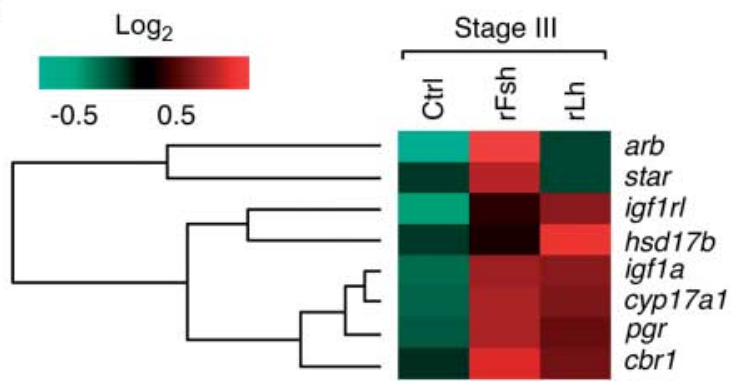

Figure 6

Hierarchical clustering of transcripts that changed significantly $(P<0.05)$ in Senegalese sole testicular explants at stages I-II (A) and III (B) after treatment with $\mathrm{rFsh}$ and/or rLh in vitro. Distances are measured using euclidean distance. Results are expressed as a matrix view of $\log _{2}$ expression levels where rows represent transcripts and columns represent the treatments. For each map, the intensity of each color denotes the standardized ratio between each value and the average expression of each transcript across all treatments. Red pixels correspond to an increased abundance of mRNA, whereas green pixels indicate decreased mRNA levels. The relative mRNA levels of all genes analyzed are shown in Supplementary Figure 2.

However, Lh was also more effective than Fsh at upregulating the expression of cyp11a1, an enzyme that initiates steroidogenesis by converting cholesterol to pregnenolone. In contrast, at stage III only cyp17a1 was upregulated by Fsh and Lh, whereas $h s d 17 b$ transcripts were accumulated only in response to Lh, despite both gonadotropins stimulating the secretion of androgens at this stage. This observation could indicating that at stage III androgens can be produced by Fsh through the stimulation of Cyp17a1-mediated production of the testosterone precursor androstenedione without the activation of downstream genes in the steroidogenic pathway. Similarly, the Lh-specific upregulation of $h s d 17 b$ at this

stage (to the same level than at stages I-II) could explain the increased production of testosterone and 11-KT with respect to that induced by Fsh.

Senegalese sole spermatids also express cyp11a1, cbr1, and cyp19a1, but the physiological significance of this observation remains unclear. In mammals, high transcriptional activity in spermatocytes and spermatids is facilitated by an overall permissive chromatin arrangement in these germ cells that results from extensive chromatin remodeling, but it may be functionally not relevant (Soumillon et al. 2013). In zebrafish, however, the presence of Cyp17a1, Cyp19a1, and Cyp19a1b in germ cells has been demonstrated by using specific antibodies (Hinfray et al. 2013). These data therefore indicate that steroids may potentially be produced locally by teleost germ cells.

The activation by Fsh and Lh of the expression of all the steroidogenesis-related genes at stages I-II, except star, was dependent on the cAMP/PKA pathway and the production of steroids, which is consistent with the coexpression of Fshra and Lhcgrba in sole Leydig cells and the possible activation of common signaling pathways. However, the steroid-independent positive regulation of star by Fsh, but not that by Lh, indicates that gonadotropins can also activate different downstream signaling pathways in somatic cells. These data are in contrast with those reported for teleosts with cystic spermatogenesis such as the rainbow trout, where gonadotropins stimulate the expression of star, $h s d 3 b$, cyp17a1, and $h s d 11 b 2$ independently from steroids (Sambroni et al. 2013a,b), although star expression can be downregulated by androgens (Rolland et al. 2013). Similarly, treatment of zebrafish testicular explants with Fsh in vitro stimulates star and cyp17a1 expression independently from steroids, while Lh has no effect (García-López et al. 2010). Altogether, our findings for sole indicate a wider steroid-dependent gonadotropic regulation of genes involved in steroidogenesis compared with other teleosts. However, at stage III most of these genes did not respond to Fsh or Lh despite the high production of androgens at this stage, probably indicating the existence of negative feedback loops of steroids regulating the expression of steroidogenic enzymes during sole late spermatogenesis (Baron et al. 2005, Rolland et al. 2013). This mechanism might be important for finetuning the local regulation of testicular steroid production to sustain spermatogenesis and the continuous differentiation of spermatids.

The expression of Senegalese sole nuclear steroid receptors ara, arb, pgr, and erb was upregulated by Fsh

Published by Bioscientifica Ltd. 

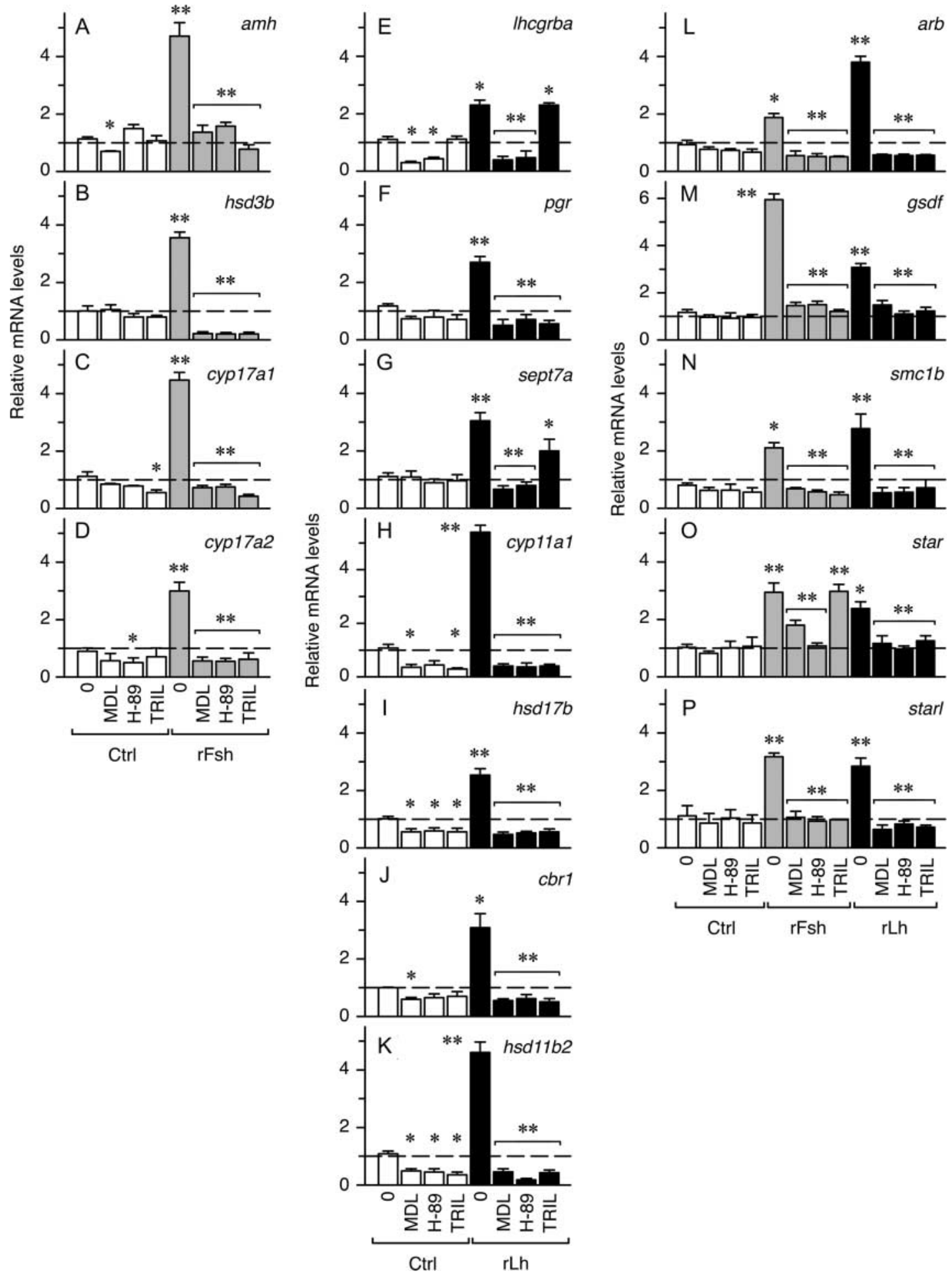

Figure 7

Effect of inhibitors of the CAMP/PKA pathway and of steroidogenesis on transcripts preferentially regulated by rFsh ((A) amh; (B) $h s d 3 b ;(C)$ cyp17a1; and (D) cyp17a2), rLh ((E) Ihcgrba; (F) pgr; (G) sept7a; (H) cyp11a1; (I) hsd17b; (J) cbr1; and (K) hsd11b2), or both ((L) arb; (M) gsdf; (N) smc1b; (O) star; and (P) starl), in testis at stages I-II in vitro. Changes in expression were determined by qRT-PCR and normalized to ef1a1 mRNA expression.
Values (mean \pm s.E.M.) are from three independent experiments, each with three replicates per condition, for three different males. Dashed line at mRNA level 1 indicates no change with respect the control group at time zero. Asterisks denote significant differences $\left({ }^{*} P<0.05 ; * * P<0.01\right)$ with respect to the untreated control group or the group treated with rFsh alone (brackets). 
and/or Lh at stages I-II, and these actions on pgr and arb were mediated by steroids. At stage III, arb and to a lesser extent $p g r$ were stimulated only by Fsh. In sole, the expression of arb was Sertoli-cell-specific, whereas the other genes were expressed not only in Sertoli cells, or in Leydig cells in the case of $e r b$, but also in spermatogonia, spermatocytes, and spermatids. The expression of steroid receptors in the germ cells of the Senegalese sole and other teleosts (Wu et al. 2001, Hanna et al. 2010, Zhou et al. 2010, Pu et al. 2013) may indicate a direct action of steroids on germ cell differentiation. However, murine loss-of-function models for some steroid receptors indicate that they are not required for germ cell development and function (Mahato et al. 2001), and therefore this mechanism remains to be demonstrated in fish. In sole, the differentiation of free tubular spermatids to spermatozoa is directly triggered by Lh (Chauvigné et al. 2014), but whether steroids have a role during early spermatid differentiation, or in the release of spermatids from Sertoli cells into the tubular lumen, is currently unknown.

Finally, at stages I-II both gonadotropins also regulated the expression of the meiosis-related gene $s m c 1 b$ in a steroid-dependent manner. This gene was expressed in germ cells enclosed within the Sertoli cells, and is potentially necessary for recombination between homologs during the meiotic prophase (Eijpe et al. 2000). Although the expression of the germ-cell-specific piwil2, which may also be involved in meiosis progression (Houwing et al. 2007), was not significantly regulated by Fsh or Lh during the stages examined, it may be possible that this gene is under gonadotropic regulation at earlier stages.

\section{Fsh mainly controls the expression of growth factors in Sertoli cells}

The members of the Tgfb superfamily, such as Gsdf and Amh, produced by Sertoli cells are positive and negative regulators, respectively, of spermatogonial proliferation and early differentiation in adult teleosts (Miura et al. 2002, Sawatari et al. 2007, Wu et al. 2010, Skaar et al. 2011, Chen et al. 2013). Accordingly, in Senegalese sole, gsdf and amh were localized exclusively in cortical Sertoli cells enclosing spermatogonia, and both transcripts were upregulated preferentially by Fsh during stages I-II. In zebrafish and trout, Fsh has no effect on testicular $g s d f$ expression (García-López et al. 2010, Sambroni et al. 2013a), but in our study Fsh strongly stimulated (approximately fivefold) the expression of this gene. In sole, the concomitant Fsh-mediated increase in $g s d f$ and the apparently antagonist gene amh remains intriguing, since in other teleosts Fsh and androgens strongly inhibit amh expression (Miura et al. 2002, García-López et al. 2010, Mazón et al. 2013, Rolland et al. 2013, Sambroni et al. $2013 a$ ). The specific role of amh during sole spermatogenesis is currently unknown, and therefore it is possible that this gene is required for germ cell proliferation as has been proposed for medaka (Oryzias latipes) during early gonadal differentiation (Shiraishi et al. 2008). It is also feasible, that because of the semicystic and asynchronous nature of the sole testis, $g s d f$ and $a m h$ are activated in Sertoli cells from different compartments. In any event, we found that the gonadotropin-induced expression of $g s d f$ and $a m h$ was steroid-mediated. In zebrafish, progestins can regulate amh and $g s d f$ expression (Chen et al. 2013), which could also be the case in Senegalese sole because $c b r 1$ and pgr expressed in Sertoli cells increased preferentially in response to Lh at stages I-II. Androgens might also be involved in the regulation of amh expression since the trout amh promoter contains androgen-responsive elements (Rolland et al. 2013), and both $h s d 17 b$ and $h s d 11 b 2$, as well as arb which is specific to Sertoli cells, are upregulated by Fsh and Lh in sole testes at stages I-II.

We also found an evidence for the differential gonadotropic regulation of the Igf1 pathway in sole, which may play a role during spermatogonial proliferation as shown in rainbow trout (Loir \& Le Gac 1994, Le Gac et al. 1996). In sole, igf1a and igflrl transcripts were detected in Sertoli and late-germ cells (spermatocytes and spermatids), respectively, and both Fsh and Lh appeared to moderately stimulate the expression of igfla at stage III, whereas Lh increased igflrl expression in germ cells. These findings could indicate a paracrine pathway in the sole testis where Igf1a peptides secreted by Sertoli cells control the differentiation of spermatocytes and/or spermatids. However, in trout and Nile tilapia (Oreochromis niloticus), results indicate the role of the igf $1 b$ paralog rather than the igf $1 a$ in controlling spermatogonial proliferation and gonadal steroidogenesis ( $\mathrm{Li}$ et al. 2012, Sambroni et al. 2013a). In Senegalese sole, it is not known whether the igflb gene also plays a role during germ cell development.

\section{Lh directly modulates the expression of spermatozoan differentiation-related genes in spermatids}

We have recently shown that ligand-activated Lhcgrba in the free spermatids of Senegalese sole directs the expression of genes involved in spermatozoan differentiation and the progression of spermiogenesis (Chauvigné et al. 2014). Using whole-testis explants, we confirmed that Lh preferentially upregulates the transcription of spermatid-

Published by Bioscientifica Ltd. 
specific genes (rsph1 and sept7a) possibly involved in the formation of the spermatozoan flagellum and the acquisition of motility (Schlecht et al. 2004, Lin et al. 2011) during stage I-II. The effect of $\mathrm{Lh}$ on testicular sept7a expression was steroid-independent, which is consistent with our previous findings showing that sept7a upregulation is mediated by direct activation of Lhcgrba in spermatids (Chauvigné et al. 2014). At stage III, however, the Lh-mediated stimulation of sept7a and $r$ shp 1 expression was no longer observed, which was possibly due to the 'dilution' of these mRNAs as a result of the increase in differentiating spermatids and spermatozoa in the medulla of the testis at this stage. Interestingly, in the rainbow trout testis, the majority of genes regulated by Fsh encode proteins expressed by somatic cells, whereas $\sim 50 \%$ of the genes regulated by Lh belong to the germ line (Sambroni et al. 2013a). Lhcgrba is expressed in zebrafish and gilthead seabream (Sparus aurata) germ cells (Chauvigné et al. 2014), and therefore the modulation of gene expression in these cells through direct activation of Lhcgrba is a mechanism that may also be present in teleosts with cystic spermatogenesis.

\section{Conclusions}

As has been recently reported for teleosts with cystic germ cell development, the results of the present study indicate that Fsh and Lh have common and distinct effects on gene expression during the semicystic and asynchronous spermatogenesis of an advanced pleuronectiform teleost. However, our findings also reveal significant differences with respect to previous fish models, which may reflect neofunctionalized gonadotropic regulatory pathways of transcription in the semicystic testis of teleosts. These differences can be summarized as follows: i) differential regulation of the Fshra, both at the translational and posttranslational level, in different testicular compartments during late spermatogenesis; ii) broader and steroidmediated regulation of steroidogenesis and nuclear receptor genes in both somatic and germ cells by Fsh and Lh; iii) steroid-dependent Fsh-positive regulation of genes encoding growth factors with potentially antagonistic effects on germ cell development ( $g s d f$ and $a m h$ ) in Sertoli cells during early/mid spermatogeneis; iv) preferential regulation of downstream genes involved in 11-KT and 17,20ß-P biosynthesis by Lh; and v) Lh-specific regulation of genes encoding spermatozoa differentiation proteins in haploid spermatids through direct interaction of Lh with Lhcgrba in these cells. These results indicate that in sole during spermatogenesis gonadotropins may activate alternative regulatory pathways in different testicular compartments to adjust the processes of cell proliferation and/or differentiation, in order to maintain a continuous reservoir of spermatids in the testis for all-year round spermiogenesis. However, in Senegalese sole, as well as in other teleosts with semicystic spermatogenesis, no information is available on the Fsh and Lh plasma levels during gonad maturation, and how changes in the circulating levels of gonadotropins can regulate the spermatogenic mechanisms in vivo remains unknown. In addition, since a limited number of candidate genes were studied in this work, it is not known whether in sole the expression of most gonadotropin-dependent genes relies on steroid production. Further studies will be necessary to corroborate this hypothesis and to elucidate the Fsh- and Lh-responsive pathways during semicystic and asynchronous germ cell development in teleosts.

\section{Supplementary data}

This is linked to the online version of the paper at http://dx.doi.org/10.1530/ JME-14-0087.

Declaration of interest

The authors declare that there is no conflict of interest that could be perceived as prejudicing the impartiality of this research.

\section{Funding}

This work was supported by the Spanish Ramón Areces Foundation (to J C), with additional financial support from the Spanish Ministry of Science and Innovation (grant number CSD2007-0002 to J V P). F C was supported by a postdoctoral fellowship (Juan de la Cierva Programme) from the Spanish Ministry of Science and Innovation, and D C was supported by a postdoctoral contract funded by grant number CSD2007-0002.

Author contribution statement

$\mathrm{FC}$ and $\mathrm{J} C$ conceived and designed the study. FC performed the tissue culture experiments, histological analysis, ISH and immunocytochemistry, and immunoblotting. F C, D C, and J V P performed the steroid determination assays, and CZ carried out the real-time PCR analyses. F C and $J C$ analyzed the results. F C drafted the manuscript, and J C and J V P edited the final version. All authors read and approved the final version of the manuscript.

\section{Acknowledgements}

The authors thank Dr O Chereguini (Instituto Español de Oceanografía, Santander, Spain) for providing Senegalese sole males.

\section{References}

Abel MH, Baban D, Lee S, Charlton HM \& O'Shaughnessy PJ 2009 Effects of FSH on testicular mRNA transcript levels in the hypogonadal mouse. Journal of Molecular Endocrinology 42 291-303. (doi:10.1677/ JME-08-0107) http://jme.endocrinology-journals.org DOI: 10.1530/JME-14-0087
(C) 2014 Society for Endocrinology Printed in Great Britain
Published by Bioscientifica Ltd. 
Agulleiro MJ, Anguis V, Cañavate JP, Martínez-Rodríguez G, Mylonas CC \& Cerdà J 2006 Induction of spawning of captive-reared Senegal sole (Solea senegalensis) using different administration methods for gonadotropinreleasing hormone agonist. Aquaculture 257 511-524. (doi:10.1016/j.aquaculture.2006.02.001)

Agulleiro MJ, Scott AP, Duncan N, Mylonas CC \& Cerdà J 2007 Treatment of GnRHa-implanted Senegalese sole (Solea senegalensis) with 11-ketoandrostenedione stimulates spermatogenesis and increases sperm motility. Comparative Biochemistry and Physiology. Part A, Molecular \& Integrative Physiology 147 885-892. (doi:10.1016/j.cbpa. 2007.02.008)

Alam MA, Kobayashi Y, Hirai T \& Nakamura M 2010 Isolation, characterization and expression analyses of FSH receptor in protogynous grouper. Comparative Biochemistry and Physiology. Part A, Molecular \& Integrative Physiology 156 364-371. (doi:10.1016/j.cbpa. 2010.03.001)

Almeida FF, Kristoffersen C, Taranger GL \& Schulz RW 2008 Spermatogenesis in Atlantic cod (Gadus morhua): a novel model of cystic germ cell development. Biology of Reproduction 78 27-34. (doi:10.1095/ biolreprod.107.063669)

Baron D, Fostier A, Breton B \& Guiguen Y 2005 Androgen and estrogen treatments alter steady state messengers RNA (mRNA) levels of testicular steroidogenic enzymes in the rainbow trout, Oncorhynchus mykiss. Molecular Reproduction and Development 71 471-479. (doi:10.1002/mrd.20229)

Cerdà J, Chauvigne F, Agulleiro MJ, Marin E, Halm S, Martínez-Rodríguez G \& Prat F 2008 Molecular cloning of Senegalese sole (Solea senegalensis) follicle-stimulating hormone and luteinizing hormone subunits and expression pattern during spermatogenesis. General and Comparative Endocrinology 156 470-481. (doi:10.1016/j.ygcen.2008.02.006)

Chauvigné F, Tingaud-Sequeira A, Agulleiro MJ, Calusinska M, Gómez A, Finn RN \& Cerdà J 2010 Functional and evolutionary analysis of flatfish gonadotropin receptors reveals cladal- and lineage-level divergence of the teleost glycoprotein receptor family. Biology of Reproduction $\mathbf{8 2}$ 1088-1102. (doi:10.1095/biolreprod.109.082289)

Chauvigné F, Verdura S, Mazón MJ, Duncan N, Zanuy S, Gómez A \& Cerdà J 2012 Follicle-stimulating hormone and luteinizing hormone mediate the androgenic pathway in Leydig cells of an evolutionary advanced teleost. Biology of Reproduction $\mathbf{8 7}$ 35. (doi:10.1095/biolreprod.112. 100784)

Chauvigné F, Zapater C, Gasol JM \& Cerdà J 2014 Germ line activation of the luteinizing hormone receptor directly drives spermiogenesis in a non-mammalian vertebrate. PNAS 111 1427-1432. (doi:10.1073/pnas. 1317838111)

Chen SX, Bogerd J, Schoonen NE, Martijn J, de Waal PP \& Schulz RW 2013 A progestin $(17 \alpha, 20 \beta$-dihydroxy-4-pregnen-3-one) stimulates early stages of spermatogenesis in zebrafish. General and Comparative Endocrinology 185 1-9. (doi:10.1016/j.ygcen.2013.01.005)

Eijpe M, Heyting C, Gross B \& Jessberger R 2000 Association of mammalian SMC1 and SMC3 proteins with meiotic chromosomes and synaptonemal complexes. Journal of Cell Science 113 673-682.

Forné I, Agulleiro MJ, Asensio E, Abián J \& Cerdà J 2009 2-D DIGE analysis of Senegalese sole (Solea senegalensis) testis proteome in wild-caught and hormone-treated F1 fish. Proteomics 9 2171-2181. (doi:10.1002/ pmic.200800696)

Forné I, Castellana B, Marín-Juez R, Cerdà J, Abián J \& Planas JV 2011 Transcriptional and proteomic profiling of flatfish (Solea senegalensis) spermatogenesis. Proteomics 11 2195-2211. (doi:10.1002/pmic. 201000296REF19=10.1210/en.2009-1227)

García-López A, Martínez-Rodríguez G \& Sarasquete C 2005 Male reproductive system in Senegalese sole Solea senegalensis (Kaup): anatomy, histology and histochemistry. Histology and Histopathology 20 1179-1189.

García-López A, Fernández-Pasquier V, Couto E, Canario AVM, Sarasquete C \& Martínez-Rodríguez G $2006 a$ Testicular development and plasma sex steroid levels in cultured male Senegalese sole Solea http://jme.endocrinology-journals.org DOI: $10.1530 / \mathrm{JME}-14-0087$ (c) 2014 Society for Endocrinology Printed in Great Britain senegalensis Kaup. General and Comparative Endocrinology 147 343-351. (doi:10.1016/j.ygcen.2006.02.003)

García-López A, Anguis V, Couto E, Canario AVM, Cañavate JP, Sarasquete C \& Martínez-Rodríguez G $2006 b$ Non-invasive assessment of reproductive status and cycle of sex steroid levels in a captive wild broodstock of Senegalese sole Solea senegalensis (Kaup). Aquaculture 254 583-593. (doi:10.1016/j.aquaculture.2005.10.007)

García-López A, Bogerd J, Granneman JC, van Dijk W, Trant JM, Taranger GL \& Schulz RW 2009 Leydig cells express follicle-stimulating hormone receptors in African catfish. Endocrinology 150 357-365. (doi:10.1210/ en.2008-0447)

García-López A, de Jonge H, Nóbrega RH, de Waal PP, van Dijk W, Hemrika W, Taranger GL, Bogerd J \& Schulz RW 2010 Studies in zebrafish reveal unusual cellular expression patterns of gonadotropin receptor messenger ribonucleic acids in the testis and unexpected functional differentiation of the gonadotropins. Endocrinology $\mathbf{1 5 1}$ 2349-2360. (doi:10.1210/en.2009-1227)

Hanna RN, Daly SC, Pang Y, Anglade I, Kah O, Thomas P \& Zhu Y 2010 Characterization and expression of the nuclear progestin receptor in zebrafish gonads and brain. Biology of Reproduction 82 112-122. (doi:10.1095/biolreprod.109.078527)

Hinfray N, Nóbrega RH, Caulier M, Baudiffier D, Maillot-Maréchal E, Chadili E, Palluel O, Porcher JM, Schulz R \& Brion F 2013 Cyp17a1 and Cyp19a1 in the zebrafish testis are differentially affected by oestradiol. Journal of Endocrinology 216 375-388. (doi:10.1530/JOE-12-0509)

Holdcraft RW \& Braun RE 2004 Hormonal regulation of spermatogenesis. International Journal of Andrology 27 335-342. (doi:10.1111/j.13652605.2004.00502.x)

Houwing S, Kamminga LM, Berezikov E, Cronembold D, Girard A, van den Elst H, Filippov DV, Blaser H, Raz E, Moens CB et al. 2007 A role for Piwi and piRNAs in germ cell maintenance and transposon silencing in zebrafish. Cell 129 69-82. (doi:10.1016/j.cell.2007.03.026)

Kusakabe M, Nakamura I, Evans J, Swanson P \& Young G 2006 Changes in mRNAs encoding steroidogenic acute regulatory protein, steroidogenic enzymes and receptors for gonadotropins during spermatogenesis in rainbow trout testes. Journal of Endocrinology 189 541-554. (doi:10.1677/joe.1.06684)

Le Gac F, Loir M, le Bail PY \& Ollitrault M 1996 Insulin-like growth factor (IGF-I) mRNA and IGF-I receptor in trout testis and in isolated spermatogenic and Sertoli cells. Molecular Reproduction and Development 44 23-35. (doi:10.1002/(SICI)1098-2795(199605)44:1<23::AID$\mathrm{MRD} 3>3.0 . \mathrm{CO} ; 2-\mathrm{V})$

Li M, Wu F, Gu Y, Wang T, Wang H, Yang S, Sun Y, Zhou L, Huang X, Jiao B et al. 2012 Insulin-like growth factor 3 regulates expression of genes encoding steroidogenic enzymes and key transcription factors in the nile tilapia gonad. Biology of Reproduction 86 163. (doi:10.1095/ biolreprod.111.096248)

Lin YH, Kuo YC, Chiang HS \& Kuo PL 2011 The role of the septin family in spermiogenesis. Spermatogenesis 1 298-302. (doi:10.4161/spmg.1.4 18326)

Loir M \& Le Gac F 1994 Insulin-like growth factor-I and -II binding and action on DNA synthesis in rainbow trout spermatogonia and spermatocytes. Biology of Reproduction 51 1154-1163. (doi:10.1095/ biolreprod51.6.1154)

Maclean JA II \& Wilkinson MF 2005 Gene regulation in spermatogenesis. Current Topics in Development Biology 71 131-197. (doi:10.1016/S00702153(05)71005-X)

Mahato D, Goulding EH, Korach KS \& Eddy EM 2001 Estrogen receptor- $\alpha$ is required by the supporting somatic cells for spermatogenesis. Molecular and Cellular Endocrinology 178 57-63. (doi:10.1016/S03037207(01)00410-5)

Marín-Juez R, Castellana B, Manchado M \& Planas JV 2011 Molecular identification of genes involved in testicular steroid synthesis and characterization of the response to gonadotropic stimulation in the Senegalese sole (Solea senegalensis) testis. General and Comparative Endocrinology 172 130-139. (doi:10.1016/j.ygcen.2011.02.003) 
Marín-Juez R, Viñas J, Mechaly AS, Planas JV \& Piferrer F 2013 Stage-specific gene expression during spermatogenesis in the Senegalese sole (Solea senegalensis), a fish with semi-cystic type of spermatogenesis, as assessed by laser capture microdissection and absolute quantitative PCR. General and Comparative Endocrinology 188 242-250. (doi:10.1016/ j.ygcen.2013.04.015)

Mattei X, Siau Y, Thiaw OT \& Thiam D 1993 Peculiarities in the organization of testis of Ophidion sp (Pisces, Teleostei). Evidence for 2 types of spermatogenesis in teleost fish. Journal of Fish Biology 43 931-937.

Mazón MJ, Zanuy S, Muñoz I, Carrillo M \& Gómez A 2013 Luteinizing hormone plasmid therapy results in long-lasting high circulating Lh and increased sperm production in European sea bass (Dicentrarchus labrax). Biology of Reproduction 88 32. (doi:10.1095/biolreprod.112.102640)

Mechaly AS, Viñas J \& Piferrer F 2012 Sex-specific changes in the expression of kisspeptin, kisspeptin receptor, gonadotropins and gonadotropin receptors in the Senegalese sole (Solea senegalensis) during a full reproductive cycle. Comparative Biochemistry and Physiology. Part A, Molecular \& Integrative Physiology 162 364-371. (doi:10.1016/j.cbpa.2012.04.003)

Menon KM, Clouser CL \& Nair AK 2005 Gonadotropin receptors: role of post-translational modifications and post-transcriptional regulation. Endocrine 26 249-257. (doi:10.1385/ENDO:26:3:249)

Miura T \& Miura C 2003 Molecular control mechanisms of fish spermatogenesis. Fish Physiology and Biochemistry 28 181-186. (doi:10.1023/B:FISH.0000030522.71779.47)

Miura T, Yamauchi K, Takahashi H \& Nagahama Y 1991a Hormonal induction of all stages of spermatogenesis in vitro in the male Japanese eel (Anguilla japonica). PNAS 88 5774-5778. (doi:10.1073/pnas.88.13.5774)

Miura T, Yamauchi K, Takahashi H \& Nagahama Y $1991 b$ Human chorionic gonadotropin induces all stages of spermatogenesis in vitro in the male Japanese eel (Anguilla japonica). Developmental Biology 146 258-262. (doi:10.1016/0012-1606(91)90468-I)

Miura T, Miura C, Ohta T, Nader MR, Todo T \& Yamauchi K 1999 Estradiol$17 \beta$ stimulates the renewal of spermatogonial stem cells in males. Biochemical and Biophysical Research Communications 264 230-234. (doi:10.1006/bbrc.1999.1494)

Miura T, Miura C, Konda Y \& Yamauchi K 2002 Spermatogenesispreventing substance in Japanese eel. Development 129 2689-2697.

Miura T, Higuchi M, Ozaki Y, Ohta T \& Miura C 2006 Progestin is an essential factor for the initiation of the meiosis in spermatogenetic cells of the eel. PNAS 103 7333-7338. (doi:10.1073/pnas.0508419103)

Ohta T, Miyake H, Miura C, Kamei H, Aida K \& Miura T 2007 Folliclestimulating hormone induces spermatogenesis mediated by androgen production in Japanese eel, Anguilla japonica. Biology of Reproduction $\mathbf{7 7}$ 970-977. (doi:10.1095/biolreprod.107.062299)

Palstra AP, Crespo D, Van den Thillart GE \& Planas JV 2010 Saving energy to fuel exercise: swimming suppresses oocyte development and downregulates ovarian transcriptomic response of rainbow trout Oncorhynchus mykiss. American Journal of Physiology. Regulatory, Integrative and Comparative Physiology 299 R486-R499. (doi:10.1152/ajpregu.00109.2010)

Planas JV \& Swanson P 1995 Maturation-associated changes in the response of the salmon testis to the steroidogenic actions of gonadotropins (GTH I and GTH II) in vitro. Biology of Reproduction 52 697-704. (doi:10.1095/biolreprod52.3.697)

Pu L, Han K, Xie F, Zou Z, Close D, Zhang Z \& Wang Y 2013 Molecular cloning, characterization, and gene expression of the androgen receptor in the large yellow croaker, Larimichthys crocea. Fish Physiology and Biochemistry 39 309-324. (doi:10.1007/s10695-012-9701-6)

Rolland AD, Lardenois A, Goupil AS, Lareyre JJ, Houlgatte R, Chalmel F \& Le Gac F 2013 Profiling of androgen response in rainbow trout pubertal testis: relevance to male gonad development and spermatogenesis. PLOS ONE 8 e53302. (doi:10.1371/journal.pone.0053302)
Sambroni E, Rolland AD, Lareyre JJ \& Le Gac F 2013a FSH and LH have common and distinct effects on gene expression in rainbow trout testis. Journal of Molecular Endocrinology 50 1-18. (doi:10.1530/JME-12-0197)

Sambroni E, Lareyre JJ \& Le Gac F 2013b Fsh controls gene expression in fish both independently of and through steroid mediation. PLOS ONE $\mathbf{8}$ e76684. (doi:10.1371/journal.pone.0076684)

Sawatari E, Shikina S, Takeuchi T \& Yoshizaki G 2007 A novel transforming growth factor- $\beta$ superfamily member expressed in gonadal somatic cells enhances primordial germ cell and spermatogonial proliferation in rainbow trout (Oncorhynchus mykiss). Developmental Biology 301 266-275. (doi:10.1016/j.ydbio.2006.10.001)

Schlecht U, Demougin P, Koch R, Hermida L, Wiederkehr C, Descombes P, Pineau C, Jégou B \& Primig M 2004 Expression profiling of mammalian male meiosis and gametogenesis identifies novel candidate genes for roles in the regulation of fertility. Molecular Biology of the Cell $\mathbf{1 5}$ 1031-1043. (doi:10.1091/mbc.E03-10-0762)

Schulz RW, Menting S, Bogerd J, França LR, Vilela DA \& Godinho HP 2005 Sertoli cell proliferation in the adult testis - evidence from two fish species belonging to different orders. Biology of Reproduction $\mathbf{7 3}$ 891-898. (doi:10.1095/biolreprod.105.039891)

Schulz RW, de França LR, Lareyre JJ, Le Gac F, Chiarini-Garcia H, Nobrega RH \& Miura T 2010 Spermatogenesis in fish. General and Comparative Endocrinology 165 390-411. (doi:10.1016/j.ygcen.2009.02.013)

Scott AP, Sumpter JP \& Stacey N 2010 The role of the maturation-inducing steroid, 17, 20ß-dihydroxypregn-4-en-3-one, in male fishes: a review. Journal of Fish Biology 76 183-224. (doi:10.1111/j.1095-8649.2009. 02483.x)

Shiraishi E, Yoshinaga N, Miura T, Yokoi H, Wakamatsu Y, Abe S \& Kitano T 2008 Müllerian inhibiting substance is required for germ cell proliferation during early gonadal differentiation in medaka (Oryzias latipes). Endocrinology 149 1813-1189. (doi:10.1210/en.2007-1535)

Skaar KS, Nóbrega RH, Magaraki A, Olsen LC, Schulz RW \& Male R 2011 Proteolytically activated, recombinant anti-Müllerian hormone inhibits androgen secretion, proliferation, and differentiation of spermatogonia in adult zebrafish testis organ cultures. Endocrinology 152 3527-3540. (doi:10.1210/en.2010-1469)

Soumillon M, Necsulea A, Weier M, Brawand D, Zhang X, Gu H, Barthès P, Kokkinaki M, Nef S, Gnirke A et al. 2013 Cellular source and mechanisms of high transcriptome complexity in the mammalian testis. Cell Reports 3 2179-2190. (doi:10.1016/j.celrep.2013.05.031)

Weltzien FA, Andersson E, Andersen Ø, Shalchian-Tabrizi K \& Norberg B 2004 The brain-pituitary-gonad axis in male teleosts, with special emphasis on flatfish (Pleuronectiformes). Comparative Biochemistry and Physiology. Part A, Molecular \& Integrative Physiology 137 447-477. (doi:10.1016/j.cbpb.2003.11.007)

Wu C, Patiño R, Davis KB \& Chang X 2001 Localization of estrogen receptor $\alpha$ and $\beta$ RNA in germinal and nongerminal epithelia of the channel catfish testis. General and Comparative Endocrinology 124 12-20. (doi:10.1006/gcen.2001.7668)

Wu GC, Chiu PC, Lyu YS \& Chang CF 2010 The expression of $a m h$ and amhr2 is associated with the development of gonadal tissue and sex change in the protandrous black porgy, Acanthopagrus schlegeli. Biology of Reproduction 83 443-453. (doi:10.1095/biolreprod.110.084681)

Zapater C, Chauvigné F, Scott AP, Gómez A, Katsiadaki I \& Cerdà J 2012 Piscine follicle-stimulating hormone triggers progestin production in gilthead seabream primary ovarian follicles. Biology of Reproduction $\mathbf{8 7}$ 111. (doi:10.1095/biolreprod.112.102533)

Zhou F, Zhao W, Zuo Z, Sheng Y, Zhou X, Hou Y, Cheng H \& Zhou R 2010 Characterization of androgen receptor structure and nucleocytoplasmic shuttling of the rice field eel. Journal of Biological Chemistry $\mathbf{2 8 5}$ 37030-37040. (doi:10.1074/jbc.M110.161968)

Received in final form 4 July 2014

Accepted 11 July 2014

Accepted Preprint published online 14 July 2014 http://jme.endocrinology-journals.org DOI: 10.1530/JME-14-0087
C 2014 Society for Endocrinology Printed in Great Britain
Published by Bioscientifica Ltd. 